\title{
IMPROVEMENT OF GAS MONITORING METHODS IN WATER OF THE HYDROGEN-WATER COOLING SYSTEM OF NPP'S TURBINE GENERATOR
}

\author{
S. V. Zaitsev ${ }^{l}$, A. Yu. Tykhomyrov ${ }^{1}$, V.V. Chychenin ${ }^{1}$, V.P. Kyshnevskyi ${ }^{1}$ \\ ${ }^{1}$ Odessa State University «Odessa Polytechnic», email: sdjavdet@ukr.net
}

DOI: https://doi.org/10.20535/2218-930012021233705

The relevance of research is to ensure and improve the reliability of turbine generators (TG) with a hydrogen-water cooling system by monitoring the content of dissolved gases in the water of a hydrogen-water cooling system with monoethanolamine (MEA) - $\mathrm{C}_{2} \mathrm{H}_{7} \mathrm{NO}$ and water vapor in the cooling hydrogen of the turbine. In this work, the influence of ultrasonic vibrations on the decomposition of a mixture of water and turbine oil, organic acids (acetic acid $-\mathrm{C}_{2} \mathrm{H}_{4} \mathrm{O}_{2}$, formic acid - $\mathrm{CH}_{2} \mathrm{O}_{2}$, oxalic acid - $\mathrm{C}_{2} \mathrm{H}_{2} \mathrm{O}_{4}$ ) or monoethanolamine was determined. The distribution coefficients values were definedd for the following dissolved gases $\mathrm{H}_{2}, \mathrm{O}_{2}, \mathrm{~N}_{2}, \mathrm{CO}, \mathrm{CH}_{4}, \mathrm{C}_{2} \mathrm{H}_{2}$, $\mathrm{C}_{2} \mathrm{H}_{4}, \mathrm{C}_{2} \mathrm{H}_{6}, \mathrm{C}_{3} \mathrm{H}_{6}, \mathrm{C}_{3} \mathrm{H}_{8}$, which are of degradation products of water mix components when exposed to ultrasonic oscillation in the following system: "dissolved gas - mixture "water + monoethanolamine» - extractant argon (Ar)». The obtained values of the Ki distribution coefficients for dissolved gases in systems "dissolved gas - mixture "water $+\mathrm{C}_{2} \mathrm{H}_{7} \mathrm{NO}$ » - extractant argon (Ar)» at a temperature of $293 \mathrm{~K}$ and a concentration of $\mathrm{C}_{2} \mathrm{H}_{7} \mathrm{NO}$ at the level of $1 \mathrm{~g} / \mathrm{dm}^{3}$ are close to similar values for dissolved gases in deionized water. The principle flow chart of multichannel gas chromatograph for detecting dissolved gases in water and steam of water in hydrogen was developed. Developed flow chart of 4-chennel gas chromatographer for defining dissolved gases in water includes the one gas chromatographer with conductivity detector, methanator, flame ionization detector, argon gas-bearing and supplementary gases of hydrogen and air.

Key words: cavitation, chromatography, gases, hydrogen, monoethanolamine, turbine generator, water.

\section{Introduction}

To producing electricity, the TBB -type turbine generators are widely used at Ukrainian NPPs.

The following cooling media are used: water $\left(\mathrm{H}_{2} \mathrm{O}\right)$ for stator coil, hydrogen $\left(\mathrm{H}_{2}\right)$ for rotor core and winding [1]. Application of $\mathrm{H}_{2}$ requires arrangement of special oil sealing of turbine generator shaft.

Herewith, the steam of water from moistened oil ingresses in volume of turbine generator hydrogen that often results in electric-based deficiencies in rotor winding and leads to corrosion of internal elements of turbine generator. While being operated, a turbine generator is affected by vibration in wide frequency range that may lead to cavitation mode in the cooling water flow [1]. It may lead to high-rise short-term temperature and pressure increasing in cooling water [2]. Herewith, pressure can reach $1000 \mathrm{MPa}$ and the temperature $5000 \mathrm{~K}$ [3]. Cooling water often contains monoethanolamine $\left(\mathrm{C}_{2} \mathrm{H}_{7} \mathrm{NO}\right)$, which characterizes the monoethanolamine water- 
chemistry [4]. In case of oxygen $\left(\mathrm{O}_{2}\right)$ availability, $\mathrm{C}_{2} \mathrm{H}_{7} \mathrm{NO}$ may be subjected to thermal and oxidative degradation [5].

Reference [1] defines that the monitoring of $\mathrm{H}_{2}$ supply in cooling $\mathrm{H}_{2} \mathrm{O}$ in TBB-type TG may be performed by gas chromatographer method (GC method). Herewith, the technical and metrological requirements for the implementation of this GC method are not established. This reference also defines that the monitoring of steam content in water and gases, $\mathrm{O}_{2}, \mathrm{~N}_{2}$ in cooling $\mathrm{H}_{2}$ in turbine generator may be carried out by using the different measurement methods. It is also defined in reference [1] that the monitoring of hydrogen supply in cooling water of TBB-type turbine generator can be carried out by using gas chromatographer method. This method was developed in 1968 and is thought to be outdated - measurement duration may last 1.5 hours. This method requires improvement according to up-to-date measurement tools.

In reference [4], it is outlined, that the man-made organic impurities (oil products) might be available in cooling water. Herewith, the possible products of their degradation under the impact of vibration and cavitation mode in the cooling water in case of monoethanolamine availability are not determined.

It was shown in [5] that the thermal and oxidative destruction of $\mathrm{C}_{2} \mathrm{H}_{7} \mathrm{NO}$ in water accumulates the following aggressive organic acids, such as $\mathrm{HCOOH}, \mathrm{CH}_{3} \mathrm{COOH}$, $\mathrm{HOCH}_{2} \mathrm{COOH}$, $\mathrm{HOOCCOOH}$, $\mathrm{HOCHCH}_{3} \mathrm{COOH}, \mathrm{H}_{2} \mathrm{NCHCH}_{3} \mathrm{COOH}$ are build up in water. The possibility of a chemical reaction of these organic acids with metal structural elements of the turbine generator and pipelines under vibration and cavitation conditions in cooling water is not shown in this work.

It was shown in [6] that, provided that MEA is present in water, acetic and oxalic acids are accumulated in it. The possibility of chemical reaction of these organic acids with metal elements of $\mathrm{TG}$ construction and pipelines is not demonstrated in this work.

The purpose of the study is to ensure the reliability of a turbine generator with a hydrogen-water cooling system with monoethanolamine $\left(\mathrm{C}_{2} \mathrm{H}_{7} \mathrm{NO}\right)$ by monitoring the content of gases such as $\mathrm{H}_{2}, \mathrm{O}_{2}, \mathrm{~N}_{2}, \mathrm{CO}$, $\mathrm{CH}_{4}, \mathrm{C}_{2} \mathrm{H}_{2}, \mathrm{C}_{2} \mathrm{H}_{4}, \mathrm{C}_{2} \mathrm{H}_{6}, \mathrm{C}_{3} \mathrm{H}_{6}, \mathrm{C}_{3} \mathrm{H}_{8}$ and of water steam that contains in the cooling hydrogen of the steam generator.

In order to achieve the purpose, the following tasks have been performed:

- defining the ultrasonic oscillation effect on degradation of water mixture with petroleum turbine oil, organic acids, (acetic acid formic acid and oxalic acid) or with monoethanolamine;

- defining the values of distribution coefficient for dissolved gases such as $\mathrm{H}_{2}, \mathrm{O}_{2}$, $\mathrm{N}_{2}, \mathrm{CO}, \mathrm{CH}_{4}, \mathrm{C}_{2} \mathrm{H}_{2}, \mathrm{C}_{2} \mathrm{H}_{4}, \mathrm{C}_{2} \mathrm{H}_{6}, \mathrm{C}_{3} \mathrm{H}_{6}, \mathrm{C}_{3} \mathrm{H}_{8}$, in the system: «dissolved gas - mixture «water + monoethanolamine» - extractant $\operatorname{argon}(\mathrm{Ar}) »$;

- development of principal flow chart of multi-channel gas chromatograph for detecting dissolved gases and water steam.

\section{Tools, materials and methods}

The research has been performed by using: fresh mineral turbine oil of $\mathrm{Tp}-30$ brand; deionized water; monoethanolamine aqueous solutions: Mixture №1 («water + $\mathrm{C}_{2} \mathrm{H}_{4} \mathrm{O}_{2}+\mathrm{CH}_{2} \mathrm{O}_{2}+\mathrm{C}_{2} \mathrm{H}_{2} \mathrm{O}_{4}$ »); Mixture №2 («water + monoethanolamine»); Mixture №3 («water + monoethanolamine + mineral turbine oil of the Tp-30 brand»). 
Concentration of each components of the mixtures (except turbine oil) $-1 \mathrm{~g} / \mathrm{dm}^{3}$. The concentration of turbine oil is $5 \mathrm{mg} / \mathrm{dm}^{3}$. Volumes of mixtures $-15 \mathrm{~cm}^{3}$. Mixtures№ 1, № 2, № 3 before using were saturated with air at a temperature $T=293 \mathrm{~K}$. In a separate experiment, the mixture № 2 was saturated with hydrogen at a temperature $\mathrm{T}=293 \mathrm{~K}$. While performing measurements the following equipment were used: gas chromatograph «Crystal 2000M» (Russia) with gas dispensers, methanator (for the conversion of $\mathrm{CO}$ and $\mathrm{CO}_{2}$ into $\mathrm{CH}_{4}$ ), thermal conductivity detector (TCD), and flame ionization detector (FID); gas chromatographer «LHM-80» (Russia) with gas dispensers and TCD detector.

Ultrasound generator «Rodnychok» (Ukraine) (irradiation frequency 35 up to $125 \mathrm{kHz}$, power 20 Watts) for acoustic irradiation of Mixtures № 1, № 2, № 3; device (extractor) for accelerating equilibrium (Russia) with a rotating drum for placing syringes in volumes of $20 \mathrm{~cm}^{3}$ or $50 \mathrm{~cm}^{3}$ with analyzed samples. Mixtures № 1, № 2, № 3 and gaseous extractants for establishing phase equilibrium in systems «Mixture - extraction solvent»; extractant argon (Ar); graduated gaseous mixtures of $\mathrm{H}_{2}, \mathrm{CH}_{4}, \mathrm{C}_{2} \mathrm{H}_{6}, \mathrm{C}_{2} \mathrm{H}_{4}$, $\mathrm{C}_{2} \mathrm{H}_{2}, \mathrm{CO}, \mathrm{CO}_{2}, \mathrm{O}_{2}, \mathrm{~N}_{2}, \mathrm{C}_{3} \mathrm{H}_{6}, \mathrm{C}_{3} \mathrm{H}_{8}$, in argon; saturated distilled water. Argon is chosen as an extractant taking into account its gasbearing properties in gas chromatograph. Measurements have been performed at a temperature of $(293 \pm 0.5) \mathrm{K}$. Duration: gas extraction of components from mixtures № 1, № 2, № 3 - 10 minutes; Ultrasound effect on the Mixture № 1, № 2, № 3 - to 2 hours at temperature of $\mathrm{T}=293 \mathrm{~K}$. The gas chromatograph registration of components has been performed by using: TCD - for $\mathrm{H}_{2}$, $\mathrm{O}_{2}, \mathrm{~N}_{2}$, water steam; FID - for $\mathrm{CH}_{4}, \mathrm{C}_{2} \mathrm{H}_{6}$,
$\mathrm{C}_{2} \mathrm{H}_{4}, \mathrm{C}_{2} \mathrm{H}_{2}, \mathrm{CO}, \mathrm{CO}_{2}, \mathrm{C}_{3} \mathrm{H}_{6}, \mathrm{C}_{3} \mathrm{H}_{8}$. Figure 1 demonstrates developed installation for performing measurements.

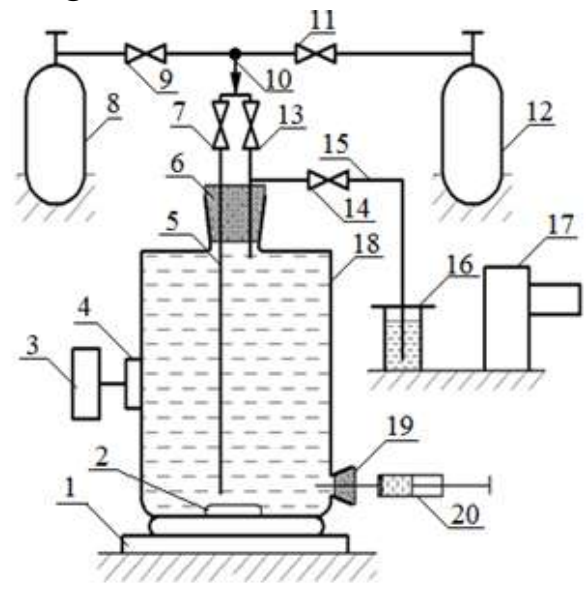

Fig. 1. Installation for measurements:

1 - magnet; 2 - magnetic stirrer; 3 ultrasound generator; 4 - ultrasonic emitter; 5, 10, 15, 21, 22 - pipelines; 6 - cover; 7, 9, $11,13,14$ - cranes; 8 - air cylinder; 12 cylinder with hydrogen; 16 - hydraulic gate valve; 17 - extractor; 18 - vessel with the mixture; 19 - mixture selection assemble; 20 - syringe

To determining the dissolved gases content in Mixtures № 1, № 2, № 3, the following was used: static way of $\mathrm{GC}$ measurement method by using gaseous extracting solvent and corresponding variants of equilibrium gas phase analysis methods in systems «Mixture - dissolved gas - gaseous extract»; method of absolute calibration in determining of dissolved gases content in gaseous extracts by using gaseous graduated mixtures. In the $\mathrm{GC}$ determination of the dissolved gas $C_{0}$ concentration in water, the calculation formulas used for two consecutive gas isothermal extractions were used:

$$
C_{0}=\frac{S_{\kappa}}{K_{z}} \cdot\left(K_{p}+\frac{V_{e}}{V_{e o}}\right),
$$

where $S_{\kappa}$ - is GC peak area for the analyzed dissolved gas after its first gas extraction; 
$K_{2}$ - graduated factor for FI detector or TCD of gas chromatograph for the analyzed dissolved gas; $V_{e o}$ - sample volume of analyzed water; $V_{e}-$ is the volume of gaseous extractant; $K_{p}-$ is the distribution coefficient for the analyzed dissolved gas in the system «Mixture - dissolved gas - gaseous extract».

The $K_{p}$ distribution coefficient is determined by the following formula:

$$
K_{p}=\frac{S_{1}}{S_{2}-S_{1}} \cdot \frac{V_{e}}{V_{e o}}
$$

where $S_{1}, S_{2}$ - are the areas of GC peaks for the analyzed dissolved gas after the first and second successive gas extraction from the Mixture № 1, № 2, № 3 .

Each value of the dissolved gas concentration was obtained as a result of five $(\mathrm{n}=5)$ parallel measurements with a confidence level of $p=0.95$.
The coefficient of normalized deviations depending on the number of degree of variance $f=n-1$, for $\mathrm{n}=5$ matters $t=2.78$. In determining the $\mathrm{H}_{2} \mathrm{O}$ content in gaseous $\mathrm{H}_{2}$, the method of absolute calibration with using the mixtures of water steam in gaseous argon was used.

\section{Results and discussions}

\subsection{Determination of ultrasonic} vibrations effect on the degradation of a mixture of water and organic acids, monoethanolamine, turbine oil.

Table 1 provides the results of determining the ultrasonic vibrations effect on the degradation of Mixtures № 1, № 2, № 3, which are saturated with air.

Table 1. The results of determining the ultrasonic vibrations effect on the degradation of deionized water mixtures with organic acids, monoethanolamine, and turbine oil

\begin{tabular}{|c|c|c|c|c|c|c|c|}
\hline \multirow{2}{*}{ Mixture } & \multicolumn{7}{|c|}{ Dissolved gas concentration, $\boldsymbol{C}_{\boldsymbol{i}}, \%$ by volume } \\
\cline { 2 - 8 } & $\mathrm{H}_{2}$ & $\mathrm{CO}$ & $\mathrm{CO}_{2}$ & $\mathrm{CH}_{4}$ & $\mathrm{C}_{2} \mathrm{H}_{2}$ & $\mathrm{C}_{2} \mathrm{H}_{4}$ & $\mathrm{C}_{2} \mathrm{H}_{6}$ \\
\hline №1 & 0.001 & 0.015 & 0.055 & 0.03 & - & - & - \\
\hline №2 & 0.001 & 0.025 & 0.07 & 0.04 & - & - & - \\
\hline №3 & 0.060 & 0.06 & 0.14 & 0.05 & 0.12 & 0.16 & 0.10 \\
\hline
\end{tabular}

In the Table 1: $C_{i}-$ concentration of dissolved $i$-th gas in the mixture, volumetric part, after irradiation of Mixtures № 1, № 2 , № 3

The Table 1 shows that the degradation of Mixture №1 or Mixture № 2, saturated with air, under the ultrasonic vibrations leads to the accumulation of dissolved gases such as $\mathrm{CH}_{4}, \mathrm{CO}, \mathrm{CO}_{2}$ in the mixture.
According to the Table 1 it follows that the degradation of Mixture № 3 containing mineral turbine oil $\mathrm{Tp}-30$ brand, leads to the accumulation dissolved gases $\mathrm{H}_{2}, \mathrm{CO}, \mathrm{CO}_{2}$, $\mathrm{CH}_{4}, \mathrm{C}_{2} \mathrm{H}_{2}, \mathrm{C}_{2} \mathrm{H}_{4}, \mathrm{C}_{2} \mathrm{H}_{6}$ in the mixture. This allows us to conclude that the compound of cooling water used in the equipment of the power plant might be controlled by the content of petroleum product in it after the oil cooling «cooled oil - cooling water» type 
turbine generator. For that the sample of this water should be subject to ultrasound treatment. The Table 2 provides the results of determining the ultrasonic vibrations effect on the degradation of the Mixture № 2, which is pre-saturated with hydrogen.

Table 2. The results of determining the ultrasonic vibrations effect on the degradation of deionized water mixtures with monoethanolamine

\begin{tabular}{|c|c|c|c|c|c|c|c|}
\hline \multirow{2}{*}{ Mixture } & \multicolumn{7}{|c|}{ Dissolved gas concentration, $\boldsymbol{C}_{\boldsymbol{i}}$, \% by volume } \\
\cline { 2 - 8 } & $\mathrm{H}_{2}$ & $\mathrm{CO}$ & $\mathrm{CO}_{2}$ & $\mathrm{CH}_{4}$ & $\mathrm{C}_{2} \mathrm{H}_{2}$ & $\mathrm{C}_{2} \mathrm{H}_{4}$ & $\mathrm{C}_{2} \mathrm{H}_{6}$ \\
\hline №2 before irradiation & 1.82 & 0.0001 & 0.002 & - & - & - & - \\
\hline №2 after irradiation & 1.7 & 0.001 & 0.004 & 0.04 & - & - & - \\
\hline
\end{tabular}

According to the Table 2: $C_{i}$ is a concentration of dissolved $i$-th gas in the mixture.

Table 2 shows the following results: before irradiation of the Mixture №2 saturated with hydrogen, the concentrations of $\mathrm{CO}$ and $\mathrm{CO}_{2}$ have values from 0.0001 to $0.002 \%$ by volume; after irradiation of a Mixture № 2 saturated with hydrogen, its degradation under the acoustic oscillations leads to the accumulation $\mathrm{CH}_{4}, \mathrm{CO}, \mathrm{CO}_{2}$ in the mixture and a decrease of hydrogen concentration. Increasing of $\mathrm{CO}_{2}$ in distilled (deionized) water raise its conductivity, that has undesirable effect for cooled electrical coil of turbine generator. It requires purification of makeup water to be brought (to be filled) in cooling system of TBB-type generator stator coil from monoethanolamine.

3.2 The results of determining the values of the distribution coefficients for dissolved gases in the "dissolved gas mixture «water + monoethanolamine» extractant argon (Ar)».

Table 3 shows the results of determining the values of the distribution coefficients of $K_{i}$ for dissolved gases $\mathrm{H}_{2}, \mathrm{O}_{2}$, $\mathrm{N}_{2}, \mathrm{CO}, \mathrm{CH}_{4}, \mathrm{C}_{2} \mathrm{H}_{2}, \mathrm{C}_{2} \mathrm{H}_{4}, \mathrm{C}_{2} \mathrm{H}_{6}, \mathrm{C}_{3} \mathrm{H}_{6}, \mathrm{C}_{3} \mathrm{H}_{8}$ in water in the systems «dissolved gas mixture «water $+\mathrm{C}_{2} \mathrm{H}_{7} \mathrm{NO}$ » - extractant argon (Ar)» at temperature of $293 \mathrm{~K}$ and a concentration of $\mathrm{C}_{2} \mathrm{H}_{7} \mathrm{NO}$ at the level of $1 \mathrm{~g} / \mathrm{dm}^{3}$.

Table 3. The results of determining the values of the $K_{i}$ distribution coefficients for dissolved gases in the systems «dissolved gas - mixture «water + monoethanolamine» - extractant argon $(A r) \gg$

\begin{tabular}{|l|l|l|l|l|l|l|l|l|l|l|}
\hline Gas & $\mathrm{H}_{2}$ & $\mathrm{O}_{2}$ & $\mathrm{~N}_{2}$ & $\mathrm{CO}$ & $\mathrm{CH}_{4}$ & $\mathrm{C}_{2} \mathrm{H}_{2}$ & $\mathrm{C}_{2} \mathrm{H}_{4}$ & $\mathrm{C}_{2} \mathrm{H}_{6}$ & $\mathrm{C}_{3} \mathrm{H}_{6}$ & $\mathrm{C}_{3} \mathrm{H}_{8}$ \\
\hline $\boldsymbol{K}_{\boldsymbol{i}}$ & 0.019 & 0.033 & 0.017 & 0.0244 & 0.037 & 1.10 & 0.13 & 0.050 & 0.22 & 0.038 \\
\hline
\end{tabular}

The Table 3 shows that the obtained values of the $K_{i}$ distribution coefficients for dissolved gases $\mathrm{H}_{2}, \mathrm{O}_{2}, \mathrm{~N}_{2}, \mathrm{CO}, \mathrm{CH}_{4}, \mathrm{C}_{2} \mathrm{H}_{2}$,
$\mathrm{C}_{2} \mathrm{H}_{4}, \quad \mathrm{C}_{2} \mathrm{H}_{6}, \quad \mathrm{C}_{3} \mathrm{H}_{6}, \quad \mathrm{C}_{3} \mathrm{H}_{8}, \quad$ in systems «dissolved gas - mixture «water $+\mathrm{C}_{2} \mathrm{H}_{7} \mathrm{NO}$ » - extractant argon (Ar)» at a temperature of 
$293 \mathrm{~K}$ and a concentration of $\mathrm{C}_{2} \mathrm{H}_{7} \mathrm{NO}$ at the level of $1 \mathrm{~g} / \mathrm{dm}^{3}$ are close to similar values for dissolved gases in deionized water [1]. This allows using of GC methods to determine these gases in a mixture of «water + $\mathrm{C}_{2} \mathrm{H}_{7} \mathrm{NO}$ ». Thus, the increasing of the dissolved gases content in the flow of the mixture «water $+\mathrm{C}_{2} \mathrm{H}_{7} \mathrm{NO}$ » after the pump, which ensures the circulation of this mixture in the hydrogen-water cooling system with MEA, may indicate the depressurization of this pump or its pipes.

3.3 The multichannel gas chromatograph structural flow chart for determination of dissolved gases in water and steam of water in gaseous hydrogen.

Figure 2 shows a structural flow chart of a 4-channel gas chromatograph for the determination of dissolved $\mathrm{H}_{2}, \mathrm{CO}, \mathrm{CO}_{2}, \mathrm{CH}_{4}$, $\mathrm{C}_{2} \mathrm{H}_{2}, \mathrm{C}_{2} \mathrm{H}_{4}, \mathrm{C}_{2} \mathrm{H}_{6}$ in water and water steam in gaseous hydrogen. If petroleum products are available in the water, their presence can be determined by the presence of dissolved gases
$\mathrm{C}_{3} \mathrm{H}_{6}, \quad \mathrm{C}_{3} \mathrm{H}_{8}, \quad \mathrm{C}_{4} \mathrm{H}_{10}, \mathrm{C}_{4} \mathrm{H}_{8}$ in $\mathrm{H}_{2} \mathrm{O}$ after treatment of water by ultrasonic oscillations according to the method described in reference [2].

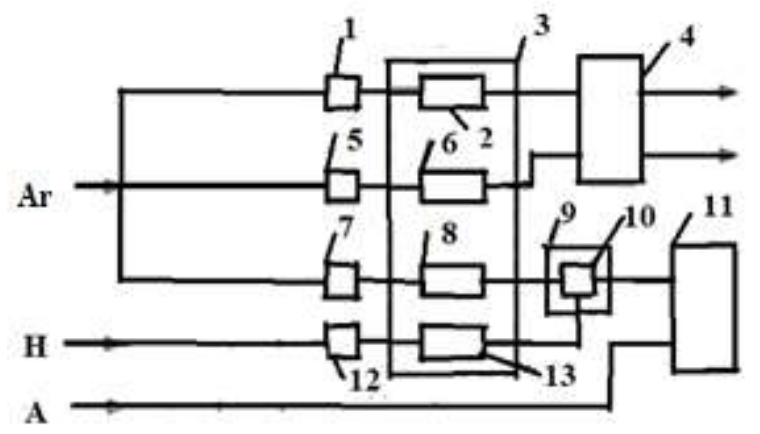

Fig. 2. Principle structural flow chart of 4channel gas chromatograph for the determination of dissolved gases in water and water steam in gaseous hydrogen: 1, 5, 7, 12 - gas dispenser taps with dosing loops; 2, 6, 8, 13 - chromatographic columns; 3, 9 heating block; 10 - methanator; 4 - thermal conductivity detector (TCD); 11 - flame ionization detector (FID); $A r, H$, $A$-argon, hydrogen, air.

Table 4. The main characteristics of the 4-channel gas chromatograph measurements elements

\section{Characteristics of chromatograph measuring channels elements}

Measuring channel № 1 to determine the water steam content in hydrogen. Elements: chromatographic column pos. 2 - sorbent «Polysorb- $1 »$; gas tap-dispenser pos. $1 ; t_{x \kappa}=393 \mathrm{~K}, t_{\partial m n}=$ $423 \mathrm{~K}$; working chamber TCD pos. 4

Measuring channel № 2 to determine the $\mathrm{H}_{2}, \mathrm{O}_{2}, \mathrm{~N}_{2}$ dissolved gases content in water. Elements: chromatographic column pos. 6 - sorbent «NaX»; gas tap-dispenser pos. $5 ; t_{x \kappa}=333 \mathrm{~K}$, $t_{\partial m n}=373-423 \mathrm{~K}$, comparative chamber TCD pos. 4.

Measuring channel № 3 to determine the $\mathrm{CO}, \mathrm{CH}_{4}, \mathrm{CO}_{2}, \mathrm{C}_{2} \mathrm{H}_{4}, \mathrm{C}_{2} \mathrm{H}_{6}, \mathrm{C}_{2} \mathrm{H}_{2}$ dissolved gases content in water. Elements: column chromatograph pos. 8 - sorbent «Porapak N 80/100»; gas tapdispenser pos. $7 ; t_{x \kappa}=313 \mathrm{~K}, t_{M}=598 \mathrm{~K}, t_{n u d}=473 \mathrm{~K}, v=12 \mathrm{~K} / \mathrm{min} . \quad t_{x \kappa}=313 \mathrm{~K}$ to $t_{x \kappa, \text { кон }}=453 \mathrm{~K}$, FID pos. 11 , Ar gas - carrier line.

Measuring channel № 4 to determine the content of $\mathrm{CH}_{4}, \mathrm{C}_{3} \mathrm{H}_{6}, \mathrm{C}_{3} \mathrm{H}_{8}, \mathrm{C}_{4} \mathrm{H}_{10}, \mathrm{C}_{4} \mathrm{H}_{8}$ dissolved gases in water. Elements: chromatographic column pos. 13 - sorbent « $\mathrm{Al}_{2} \mathrm{O}_{3 »}$; gas tap-dispenser pos. $12 ; t_{x \kappa}=313 \mathrm{~K}, t_{M}=598 \mathrm{~K}, t_{n u d}=473 \mathrm{~K}, v=12 \mathrm{~K} / \mathrm{min}$ from $t_{x \kappa}=313 \mathrm{~K}$ to $t_{x \kappa, \text { кон }}=453 \mathrm{~K}$, FID pos. $11, \mathrm{H}_{2}$ line 
According to the table 4 table: $t_{x \kappa}, t_{\partial m n}$, $t_{\text {пид}}, t_{M}, t_{x к, к о н}, t_{\text {исn }}-$ temperatures of

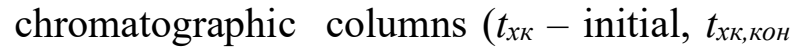
- final), TCD, FID, methanator, K; $v$ - is the heating rate of $\mathrm{GC}$ columns, $\mathrm{K} / \mathrm{min}$.

During the development of the structural flow chart of 4-channel gas chromatograph for the determination of dissolved gases in water and water steam in gaseous hydrogen, was defined the following:

1. The developed structural flow chart includes: gas taps-dispensers with calibrated dosing loops; GC columns; thermostats; detectors - TCD and FID; gas supply lines $\mathrm{Ar}, \mathrm{H}_{2}$, air. This technical solution allows measuring the content of gases $\mathrm{H}_{2}, \mathrm{~N}_{2}, \mathrm{O}_{2}$, $\mathrm{CO}, \mathrm{CH}_{4}, \mathrm{CO}_{2}, \mathrm{C}_{2} \mathrm{H}_{4}, \mathrm{C}_{2} \mathrm{H}_{6}, \mathrm{C}_{2} \mathrm{H}_{2}, \mathrm{C}_{3} \mathrm{H}_{6}$, $\mathrm{C}_{3} \mathrm{H}_{8}, \mathrm{C}_{4} \mathrm{H}_{8}, \mathrm{C}_{4} \mathrm{H}_{10}$ y $\mathrm{H}_{2} \mathrm{O}$ in water and water steam taken from one sample of water or gaseous hydrogen by the using of one 4-x channel gas chromatograph.

2. The calculated value of the limits for determining the humidity of gaseous hydrogen has a value of $0.16 \mathrm{~g} / \mathrm{m}^{3}$. Relative error of the measurement result is no more $40 \%$ with a confidence level $\mathrm{p}=0.95$. The estimated value of the detection limits of water steam is $1.6 \cdot 10^{-7} \mathrm{~g}$. Calibration samples of water steam in gaseous argon are introduced into the chromatograph using a gas tap-dispenser pos. 1.

3. To determining the content of $\mathrm{CO}$, $\mathrm{CH}_{4}, \mathrm{CO}_{2}, \mathrm{C}_{2} \mathrm{H}_{4}, \mathrm{C}_{2} \mathrm{H}_{6}, \mathrm{C}_{2} \mathrm{H}_{2}$ y $\mathrm{H}_{2} \mathrm{O}$ gases in water, the equilibrium gas sample (or calibration mixtures of gases) is introduced into the chromatograph using a gas tapdispenser pos. 7 .

4. To determining the content of $\mathrm{CH}_{4}$, $\mathrm{C}_{3} \mathrm{H}_{6}, \mathrm{C}_{3} \mathrm{H}_{8}, \mathrm{C}_{4} \mathrm{H}_{10}, \mathrm{C}_{4} \mathrm{H}_{8}$ gases in water, equilibrium gas sample (or calibration mixtures of gases) is introduced into the chromatograph using a gas tap-dispenser pos. 12 .

5. To determining the content of $\mathrm{H}_{2}, \mathrm{O}_{2}$, $\mathrm{N}_{2}$ gases in $\mathrm{H}_{2} \mathrm{O}$, equilibrium gas sample (or calibration mixtures of gases) is inserted into the chromatograph using a gas tap-dispenser pos. 5 .

Table 5 provides the limits of allowable relative error values of the detecting of measuring gases concentrations $\left(\delta_{i}, \% \mathrm{Rel}\right)$ and water steam, depending on the range of their concentrations of $C_{i}$.

Table 5. The value of the allowable relative error $\delta_{i}$ and determining the concentrations of measuring gases and water steam depending on their concentrations range

\begin{tabular}{|c|c|c|c|c|}
\hline \multicolumn{4}{|c|}{ The range of measuring dissolved gases concentrations of $C_{i}, \%$ by volume, } & \multirow[t]{2}{*}{$\delta_{i}, \%$} \\
\hline $\begin{array}{c}\mathrm{H}_{2}, \mathrm{O}_{2}, \mathrm{~N}_{2} \text { in water; } \\
\text { water steam in } \\
\text { hydrogen }\end{array}$ & $\begin{array}{c}\mathrm{CH}_{4}, \mathrm{C}_{2} \mathrm{H}_{4}, \mathrm{C}_{2} \mathrm{H}_{6}, \mathrm{C}_{3} \mathrm{H}_{6}, \\
\mathrm{C}_{3} \mathrm{H}_{8}, \mathrm{C}_{4} \mathrm{H}_{8}, \mathrm{C}_{4} \mathrm{H}_{10}\end{array}$ & $\mathrm{C}_{2} \mathrm{H}_{2}$ & $\mathrm{CO}, \mathrm{CO}_{2}$ & \\
\hline$<5 \cdot 10^{-3}$ & $<10^{-3}$ & $<5 \cdot 10^{-4}$ & $<5 \cdot 10^{-3}$ & $<50$ \\
\hline$(5-25) \cdot 10^{-3}$ & $(1-3) \cdot 10^{-3}$ & $(5-15) \cdot 10^{-4}$ & $(5-25) \cdot 10^{-3}$ & $<50$ \\
\hline$(25-50) \cdot 10^{-3}$ & $(3-50) \cdot 10^{-3}$ & $(1,5-25) \cdot 10^{-3}$ & $(25-100) \cdot 10^{-3}$ & $\leq 20$ \\
\hline$>5 \cdot 10^{-2}$ & $>5 \cdot 10^{-2}$ & $>5 \cdot 10^{-2}$ & $>0,1$ & $\leq 10$ \\
\hline
\end{tabular}

The value of standard deviation of the output signal (RSD, \% Rel) for TCD, FID gas chromatograph (height, area, retention time for the measured dissolved gas) depending on 
the range of concentrations of the measured dissolved gas $(\mathrm{Ci}, \%)$ given in Table 6 .

Table 6. The value of the standard deviation of RSD

\begin{tabular}{|c|c|c|c|c|c|}
\hline $\boldsymbol{C}_{\boldsymbol{i}}$ \% \% by volume & $<0.002$ & $0.002-0,01$ & $0.01-0.1$ & $0.1-1$ & $1-10$ \\
\hline RSD. \% rel. & $>10$ & 10 & 2 & 2 & 1 \\
\hline
\end{tabular}

Table 7 shows the experimentally obtained values of the limits for the determination of $C_{n o}$ (volumetric \%) the concentrations of dissolved gases in water to performing measurements.

Table 7. Limits of dissolved gases concentrations values in water

\begin{tabular}{|c|c|c|c|c|c|}
\hline № & Dissolved gas & $\boldsymbol{C}_{\boldsymbol{n} \text { o, \% by volume }}$ & № & Dissolved gas & $\boldsymbol{C}_{\boldsymbol{n} \text {, }}$ \% by volume \\
\hline 1 & $\mathrm{H}_{2}$ & $2 \cdot 10^{-4}$ & 4 & $\mathrm{CO}_{2} \mathrm{CO}_{2}$ & $5 \cdot 10^{-4}$ \\
\hline 2 & $\mathrm{CH}_{4}, \mathrm{C}_{2} \mathrm{H}_{6}, \mathrm{C}_{2} \mathrm{H}_{4}$ & $1 \cdot 10^{-4}$ & 5 & $\mathrm{O}_{2}, \mathrm{~N}_{2}$ & $1.5 \cdot 10^{-4}$ \\
\hline 3 & $\mathrm{C}_{2} \mathrm{H}_{2}$ & $5 \cdot 10^{-5}$ & & & \\
\hline
\end{tabular}

To determine the limits of measuring of the concentrations of water steam in gaseous hydrogen and calibration of the chromatograph, mixtures of water steam in gaseous argon at concentrations of water steam from $0.16 \mathrm{~g} / \mathrm{m}^{3}$ to $17 \mathrm{~g} / \mathrm{m}^{3}$ were used. To determine the limits of measuring the concentrations of gases $\mathrm{H}_{2}, \mathrm{CH}_{4}, \mathrm{C}_{2} \mathrm{H}_{6}, \mathrm{C}_{2} \mathrm{H}_{4}$, $\mathrm{C}_{2} \mathrm{H}_{2}, \mathrm{CO}, \mathrm{CO}_{2}, \mathrm{O}_{2}, \mathrm{~N}_{2}, \mathrm{C}_{3} \mathrm{H}_{6}, \mathrm{C}_{3} \mathrm{H}_{8}, \mathrm{C}_{4} \mathrm{H}_{10}$, $\mathrm{C}_{4} \mathrm{H}_{8}$ in water and calibrate of chromatographic mixtures of these gases in gaseous argon at concentrations for each of the measured gases on the level of $0.5 \%$.

\section{Conclusion}

1. The ultrasonic oscillations effect on the degradation of a water mixture and petroleum turbine oil, organic acids (acetic acid formic acid and oxalic acid) or with monoethanolamine was determined. Degradation products are the following gases $\mathrm{H}_{2}, \mathrm{CO}, \mathrm{CO}_{2}, \mathrm{CH}_{4}, \mathrm{C}_{2} \mathrm{H}_{2}, \mathrm{C}_{2} \mathrm{H}_{4}, \mathrm{C}_{2} \mathrm{H}_{6}$. It enables to develop the $\mathrm{GC}$ monitoring methods to increase the operation reliability of TBB-type turbine generator.

2. The values of distribution coefficients for dissolved gases such as $\mathrm{H}_{2}, \mathrm{CO}, \mathrm{CO}_{2}$, $\mathrm{CH}_{4}, \mathrm{C}_{2} \mathrm{H}_{2}, \mathrm{C}_{2} \mathrm{H}_{4}, \mathrm{C}_{2} \mathrm{H}_{6}, \mathrm{C}_{3} \mathrm{H}_{6}, \mathrm{C}_{3} \mathrm{H}_{8}, \mathrm{C}_{4} \mathrm{H}_{10}$, $\mathrm{C}_{4} \mathrm{H}_{8}$ in the mixture «dissolved gas - mixture «water $+\mathrm{C}_{2} \mathrm{H}_{7} \mathrm{NO}$ » - extractant (Ar)» are determined. The obtained values of distribution coefficients for dissolved gases at $\mathrm{T}=293 \mathrm{~K}$ and $\mathrm{C}_{2} \mathrm{H}_{7} \mathrm{NO}$ concentration of $1 \mathrm{~g} / \mathrm{dm}^{3}$ are close to similar values for dissolved gases in deionized water. It enables to determine the content of these dissolved gases in water by GC methods.

3. The principle structural flow chart of a 4-channel gas chromatograph for determination of $\mathrm{H}_{2}, \mathrm{CO}, \mathrm{CO}_{2}, \mathrm{CH}_{4}, \mathrm{C}_{2} \mathrm{H}_{2}$, $\mathrm{C}_{2} \mathrm{H}_{4}, \mathrm{C}_{2} \mathrm{H}_{6}, \mathrm{C}_{3} \mathrm{H}_{6}, \mathrm{C}_{3} \mathrm{H}_{8}, \mathrm{C}_{4} \mathrm{H}_{8}, \mathrm{C}_{4} \mathrm{H}_{10}$ and water steam in gaseous hydrogen has been developed. This made it possible to determine these components using a single gas chromatograph, which simplifies and reduces the cost of measurements. 
5. These technical solutions enable to ensure and increase the operation reliability of the turbine generator with hydrogen cooling by the monitoring of dissolved gases in the water cooling of hydrogen-water cooling system using ethanolamine and the monitoring water steam in the cooling hydrogen of TG of TBB-type.

\section{References}

1. Avdeeva, AA «Chromatography in energy». M.: Energiya, 1980, 272 p.

2. Sizykh M. R.; Batoeva, AA; Aseev, D.G. «Cavitation activation of deironing processes of natural groundwater». International Journal of Applied and Basic Research. 2018, 12 (1), 9-14.

3. Wang, S.; Zhou, N.; Wu, S.; Zhang, Q.; Yang Z. «Modeling the Oxidation Kinetics of Sonoactivated Persulfates Process on the Degradation of Humic Acid». Ultrasonics Sonochemistry. - 2015, $23,128-134$.
4. Water-chemical of reactor coolant pumps of large energy facilities: monograph: V.A. Kyshnevskiy. V.V. Chychenyn, P.Ya. Pavlyshin, V.N. Bondarenko, A.Yu. Tikhomirov; under V.A. Kyshnevskyi. Odessa: Astroprint, 2018, 250 p.

5. Talzi, V.P. "Investigation of the aqueous solution composition of monoethanolamine used to absorb $\mathrm{CO}_{2}$, from fuel gases by $\mathrm{NMR} »$. Journal of Organic Chemistry, 2016, 52 (7), 935-939.

6. Kuznetsov, PN; Tykhomyrov, A.Yu.; Kustove N.A. «Comprehensive assessment of the maintenance and maintenance of the water-chemistry of the Rivne NPP units № 1-4 secondary circuit with corrective treatment with ethanolamine». Nuclear Energy and the Environment, 2017, 1 (9), 30-36. 


\title{
УДОСКОНАЛЕННЯ МЕТОДІВ КОНТРОЛЮ ГАЗІВ У ВОДІ СИСТЕМИ ВОДНЕВО-ВОДНОГО ОХОЛОДЖЕННЯ ТУРБОГЕНЕРАТОРА ЕЛЕКТРОСТАНЦІЇ
}

\author{
С.В. Зайцев ${ }^{1}$, А.Ю. Тихомиров ${ }^{1}$, В.В. Чиченін ${ }^{1}$, В.П. Кишневський \\ ${ }^{1}$ Державний університет «Одеська політехніка », email: sdjavdet@ukr.net
}

\begin{abstract}
Актуальність дослідження полягає у забезпеченні та підвищені надійності експлуатачії турбогенератора з системою воднево-водного охолодження. Метою дослідження $\epsilon$ забезпечення надійності експлуатачії турбогенератора з водневим охолодженням за рахунок контролю вмісту розчинених газів у воді системи воднево-водного охолодження із моноетаноламіновим ( $\left.\mathrm{C}_{2} \mathrm{H}_{7} \mathrm{NO}\right)$ водно-хімічним режимом та пару води в охолоджуючому водні турбогенератора. Завданнями дослідження є визначення впливу ультразвукових коливань на деградаџію сумімі води із турбінною оливою, органічними кислотами ( оцтовою - $\mathrm{C}_{2} \mathrm{H}_{4} \mathrm{O}_{2}$, мурашиною $-\mathrm{CH}_{2} \mathrm{O}_{2}$, щзавлевою $-\mathrm{C}_{2} \mathrm{H}_{2} \mathrm{O}_{4}$ ) або із моноетаноламіном; визначення значень коефіцієнтів розподілу для розчинених газів $\mathrm{H}_{2}$, $\mathrm{O}_{2}, \mathrm{~N}_{2}, \mathrm{CO}, \mathrm{CH}_{4}, \mathrm{C}_{2} \mathrm{H}_{2}, \mathrm{C}_{2} \mathrm{H}_{4}, \mathrm{C}_{2} \mathrm{H}_{6}, \mathrm{C}_{3} \mathrm{H}_{6}, \mathrm{C}_{3} \mathrm{H}_{8}$ у суміші «розчинений газ - суміш «вода +моноетаноламін» - екстрагент аргон (Аr)»; розробка принцииоової структурної схеми багатоканального газового хроматографу для визначення у воді розчинених газів та пару води у водні. При визначені впливу ультразвукових коливань на деградацію сумімі води із нафтовою турбінною оливою, органічними кислотами або із моноетаноламіном, продуктами деградаиіï $\epsilon$ гази $\mathrm{H}_{2}, \mathrm{CO}, \mathrm{CO}_{2}, \mathrm{CH}_{4}, \mathrm{C}_{2} \mathrm{H}_{2}, \mathrm{C}_{2} \mathrm{H}_{4}, \mathrm{C}_{2} \mathrm{H}_{6}$. При визначенні коефімієнтів розподілу $K_{i}$ для розчинених газів у суміші «розчинений газ - суміш «вода +моноетаноламін» - екстрагент Аг» значення Кі при концентрації моноетаноламіну 1 г/дм близькі для аналогічних значень у дистильованій воді. Розроблена принцииова структурна схема 4-х канального газового хроматографу для визначення у воді розчинених газів та пару води у водні дозволяє визначати вміст розчинених газів у воді та пару води у водні із залученням одного газового хроматографу із детектором за теплопровідністю, метанатором, полум'яно-іонізаційним детектором, газом-носієм аргоном та допоміжними газами воднем і повітрям.
\end{abstract}

Ключові слова: кавітація, хроматографія, гази, водень, моноетаноламін, турбінний генератор, вода. 